Purdue University

Purdue e-Pubs

Purdue CIBER Working Papers

Krannert Graduate School of Management

$1-1-1994$

Firm Strategy and Economic Exposure to Foreign Exchange Rate Movements

Kent D. Miller

Purdue University

Jeffrey J. Reuer

Purdue University

Follow this and additional works at: http:// docs.lib.purdue.edu/ciberwp

Miller, Kent D. and Reuer, Jeffrey J., "Firm Strategy and Economic Exposure to Foreign Exchange Rate Movements" (1994). Purdue CIBER Working Papers. Paper 93.

http://docs.lib.purdue.edu/ciberwp/93

This document has been made available through Purdue e-Pubs, a service of the Purdue University Libraries. Please contact epubs@purdue.edu for additional information. 


\title{
FIRM STRATEGY AND ECONOMIC EXPOSURE TO FOREIGN EXCHANGE RATE MOVEMENTS
}

\author{
Kent D. Miller \\ Purdue University \\ Jeffrey J. Reuer \\ Purdue University
}

94-016
Center for International Business Education and Research Purdue University Krannert Graduate School of Management 1310 Krannert Building
West Lafayette, IN $47907-1310$
Phone: (317) 494-4463
FAX: (317) 494-9658


FIRM STRATEGY AND ECONOMIC EXPOSURE

TO FOREIGN EXCHANGE RATE MOVEMENTS

\author{
KENT D. MILLER \\ JEFFREY J. REUER \\ Krannert Graduate School of Management \\ Purdue University \\ 1310 Krannert Building \\ West Lafayette, IN 47907-1310 \\ (317) 494-5903 \\ BITNET: kmiller@purccvm.bitnet
}

October 24, 1994

The authors wish to thank Yakov Amihud for comments on an earlier draft. 


\section{FIRM STRATEGY AND ECONOMIC EXPOSURE}

TO FOREIGN EXCHANGE RATE MOVEMENTS

This study examines the impiications of differences in strategy and industry structure for firms' economic exposures to foreign exchange rate movements. Analysis of exchange rate data indicates previous empirical research using a single exchange rate proxy understates economic exposures. This study estimated firms' exposures using a multivariate model. The empirical evidence from U.S. manufacturing firms indicates that foreign direct investment reduces economic exposure to foreign exchange rate movements. 


\section{FIRM STRATEGY AND ECONOMIC. EXPOSURE \\ TO FOREIGN EXCHANGE RATE MOVEMENTS}

Economic exposure considers the sensitivity of the real value of a company to fluctuations in real foreign exchange rates (Adler \& Dumas, 1984; Garner \& Shapiro, 1984; Shapiro, 1992). This focus on economic valuation contrasts with accounting-based transaction and translation exposures defined in terms of the book values of assets and liabilities denominated in foreign currencies. In a simple single-currency model, the economic exposure of an asset can be estimated from time series data as the coefficient computed by regressing shareholder returns on the percentage change in a foreign exchange rate (e.g., Booth \& Rotenberg, 1990).

Dufey's (1972) arguments for the conceptual superiority of economic exposure over accountingbased exposures are now widely accepted among finance scholars. Despite the conceptual appeal of economic exposure, empirical research estimating exposure coefficients has been quite limited.

Furthermore, due to methodological shortcomings in the previous research, it is difficult to reach definitive conclusions regarding corporate economic exposures to foreign exchange rate movements.

One key shortcoming in all of the previous empirical research on economic exposure is the use of a single proxy for foreign exchange rate movements. Booth and Rotenberg (1990) considered movements in the Canadian dollar relative to the U.S. dollar to the exclusion of all other foreign currencies that could affect the stock returns of Canadian companies. Studies by Amihud (1994), Bodnar and Gentry (1993), and Jorion (1990) used trade-weighted sums of major currencies as their foreign exchange proxies. In constructing their indices, Jorion (1990) and Bodnar and Gentry (1993) aggregated nominal exchange rates while Amihud (1994) used real exchange rates.

Given the volatility in many currencies' nominal exchange rates, trade-weighted sums of nominal currency rates are unlikely to be meaningful proxies for aggregate exchange rate movements. Weighted sums of nominal exchange rates including strong currencies (e.g., the Deutsche Mark) and hyperinflationary currencies (e.g., the Brazilian Cruzeiro) are not comparable over time. Despite the constant trade-based weights, differences in inflation rates effectively change over time the relative weights of the currencies in indices using nominal rates. Hence, trade-weighted sums of nominal exchange rates are poor proxies for 
exchange rates and are unlikely to provide meaningful exposure coefficient estimates.

Even using real exchange rates to construct an index is problematic. Such a methodology assumes additivity among real rates, thereby overlooking the divergent paths of real exchange rates over time. Not only may exchange rates be less than perfectly correlated, they may move in opposite directions. Hence, a single sum of positively-weighted real exchange rates may be inadequate to capture the variability in foreign exchange rates over time. Single currency or weighted-sum currency models of economic exposure may underestimate corporate exposures by omitting variables needed to capture the movements in currencies. The possibility that multiple currencies may be relevant to explaining corporate returns to shareholders has not been explored in previous empirical research.

A second major shortcoming of the existing empirical research on economic exposure to foreign exchange movements has been the frequent focus on the exposure of aggregations of firms rather than firmspecific exposures. The units of analysis found in these studies are industries or portfolios of firms from various industries. Bodnar and Gentry (1993) compared two-digit SIC code industry portfolio returns for Canada, Japan, and the U.S. They found between 20 and 35 percent of industries had significant exchange rate exposures, with the proportion varying across the three countries. Amihud (1994) examined the exposure of a portfolio of thirty-two large U.S. exporting companies. He found no evidence for significant portfolio exposures when modeling contemporaneous or lagged effects of foreign exchange movements on portfolio returns.

The problem with studies examining the economic exposure of industries or multi-industry portfolios is that such aggregations of firms may mask important differences in firm-specific strategies and hedging practices affecting foreign exchange exposures. Not only may some firms have significant exposures while others do not, the signs of the significant exposures may vary, even within an industry. The implicit assumption in models aggregating firms at the industry level is that no heterogeneity exists within industries.

Studies by Jorion (1990) and Booth and Rotenberg (1990) are unique in examining firm-specific exposures, yet these studies so diverge in their findings that we can reach no conclusion regarding the extent to which corporations are exposed to foreign exchange rates. Jorion (1990) found just 15 of 287 U.S. 
multinational firms had significant foreign exchange exposure coefficients (using a two-tailed test at the .05 level). In sharp contrast, Booth and Rotenberg (1990) reported two-thirds of their sample of 156 Canadian firms had significant exposures to movements in the Canadian dollar relative to the U.S. dollar (using a single-tail test at the .05 level).

This study sought to address the methodological shortcomings encountered in previous research examining corporate economic exposures to foreign exchange rates. Recognizing that heterogeneity in corporate strategies may result in different exposures to foreign exchange rate movements, we adopted the firm as the relevant unit of analysis. Drawing from economics and strategy research, the study developed and tested a set of hypotheses linking foreign exchange exposure to firm-specific strategies and industry integration across borders.

In contrast to previous studies, this research offers evidence that single proxies do not adequately capture the variability in foreign exchange movements. Therefore, we present a multivariate model of corporate foreign exchange exposure. Estimated coefficients from the multivariate model provide the basis for testing the implications of strategy differences across firms for foreign exchange exposures.

\section{THEORY AND HYPOTHESES}

The hypotheses developed in this section relate foreign exchange exposure to corporate strategy and industry characteristics. We focus on three strategy dimensions hypothesized to affect corporate economic exposure to foreign exchange movements. The first two hypotheses contrast the effects on exposure of foreign market entry through exports and foreign direct investment. Distinguishing the exposure effects of these two international market entry modes contrasts with Jorion (1990) and Booth and Rotenberg (1990) who made no such distinction and simply looked at the effect of foreign sales intensity on foreign exchange exposure. The stated hypotheses suggest entry through exporting may have very different implications for foreign exchange exposure than entry through direct investment. The third hypothesis considers the implications of product differentiation on corporate exposures. The final hypothesis relates the extent of international product market integration to foreign exchange exposure. 
Using the traditional accounting concept of transaction exposure, exposure to foreign exchange movements increases with the proportion of export sales to total corporate sales. This is due to firms holding receivables denominated in foreign currencies. If the home country reference currency is the dollar, dollar appreciation results in a decreased value of receivables denominated in other currencies.

The relation of export sales intensity to economic exposure considers not only the value of receivables but also the effect of foreign exchange rate movements on future sales. It is widely expected that appreciation of the home country currency decreases the competitiveness of a firm in foreign export markets (Shapiro, 1975). The cost disadvantage relative to import-substituting firms in export markets or firms based in countries with stable or declining real currency values should result in a reduction in export profits. Following similar reasoning, both Booth and Rotenberg (1990) and Jorion (1990) contended stock returns decrease when the home currency appreciates, and this exposure increases with the proportion of sales outside the home country.

While this contention represents the general consensus found in previous research on foreign exchange exposure, whether home currency appreciation has a positive or negative effect on the earnings of exporters remains an open question. This question turns on key assumptions regarding demand shifts and the behavior of competitors in response to foreign exchange rate movements (Luehrman, 1990). Luehrman (1991) presented evidence from the automobile and steel industries which generally did not support the contention that firms benefit from a depreciation of their home currency.

Our concern is not with whether the exposure of exporters to movements in their home currency is positive or negative. Rather, we consider the hypothesis:

\section{H1: The proportion of exports to total sales increases foreign exchange exposure.}

In contrast with this hypothesis regarding export-intensity, international strategy researchers have proposed that firms can reduce their exposures to uncertain environmental contingencies through participation in various country markets (Campa, 1994; Kogut, 1983; Kogut \& Kulatilaka, 1994; Lessard \& Lightstone, 1986; Lessard \& Nohria, 1990). Since countries are at different stages in business or product life cycles, returns to subsidiary operations in different countries should be less than perfectly correlated, reducing the volatility of corporate profits relative to a firm operating in a single country. By itself, 
however, this risk reduction is unlikely to be a value-creating form of international diversification relative to international portfolio diversification by individual investors. Rather, the argument for shareholder value creation from having a presence in more than one country turns on the strategic options created by foreign direct investment. Having subsidiaries operating outside the home market may provide unique options unavailable to purely domestic firms for sourcing inputs and locating production, marketing, or other value chain activities (Dixit, 1989; Kester \& Luehrman, 1989; Kogut, 1983; Kogut \& Kulatilaka, 1994). Khoury, Nickerson, and Sadanand (1991) developed a model in which exchange rate uncertainty induces firms to precommit to international markets in order to lead the industry in shifting production to low cost countries. To the extent that such flexibility provides competitive advantage (and equity markets perceive the value of the strategic options associated with foreign direct investment), value is enhanced.

A further caveat in this argument is that shareholder value creation would not result if comparable financial market hedging products were available for lower transaction costs than purchasing strategic options. Hence, implicit in the argument for investment in strategic options is the contention that alternative financial market instruments are not available to fully hedge corporate exposures. This argument would seem to hold true for exposures to many input prices, competitive and product market contingencies, and technological changes. At first glance, it may appear difficult to imagine the purchase of strategic options having a lower transaction cost than the purchase of financial market hedging instruments for managing foreign exchange risk (e.g., currency forward and future contracts, options, and swaps). Nevertheless, financial markets for foreign exchange are incomplete. The terms for exercising currency options are generally much less than the duration of corporate economic exposures. Investment in a foreign subsidiary provides an option with a term as long as the duration of the subsidiary's operations. Hence, even in the presence of financial market currency hedging instruments, we should expect some further risk-reduction associated with establishing foreign subsidiaries.

Further support for the risk-reduction associated with multinational expansion is provided by the observation that corporations generaliy use financial market currency hedges only to manage short-term transaction exposures (Batten, Mellor, \& Wan, 1993; Rawls \& Smithson, 1990). While these instruments may also be used to manage translation exposure, this is not a widespread practice. Only a few large 
multinationals have implemented economic exposure assessment and management using financial market instruments (Kohn, 1990; Lewent \& Kearney, 1990).

Viewing foreign direct investment as creating options for sourcing, production, and sales motivates the following hypothesis:

\section{H2: The proportion of foreign assets to total assets decreases foreign exchange exposure.}

Apart from the arguments relating the extent of foreign market involvement to foreign exchange exposure, other strategy components may influence a firm's foreign exchange exposure. Porter (1990) argued firms engaging in differentiation strategies have more sustainable competitive advantage than cost leaders under conditions of currency volatility. Product differentiation through investments in "higherorder" advantages (e.g., proprietary technology, unique product characteristics, or brand reputation) strengthen the firm's capability to pass through to customers changes in costs due to currency movements. Passing on cost increases to customers will not be feasible using a cost leadership strategy in the presence of competing firms with lower cost sourcing opportunities. The ability to pass through currency rate fluctuations to customers depends on the price elasticity of customer demand, which, in turn, depends on the degree of product differentiation (Sundaram \& Mishra, 1991; Shapiro, 1992: 231).

While economists acknowledge the empirical question of the extent of currency pass-through, their empirical research has looked at the industry rather than the firm as the unit of analysis (e.g., Ceglowski, 1989; Knetter, 1989; Krugman, 1987; Mann, 1986). As such, the economics literature does not explicitly consider differences within industries in firms' abilities to pass through to customers changes in costs due to exchange rate movements. Froot and Klemperer (1989) developed a model in which exporters seek to increase margins rather than market share when the importing country currency appreciates. As they explain, trading off future market share for a current margin increase enhances the value of the firm only if consumers experience switching costs or are loyal to a particular brand based on its perceived differentiated characteristics. Following Porter (1990), we hypothesize that differentiation strategies result in more sustainable competitive advantage in the presence of foreign exchange rate movements. 
One indicator of firm-specific investment in higher-order-advantages is the intensity of investment in research and development (Shapiro, 1992: 256). R\&D intensity serves as a proxy for the development of underlying resources which, directly or indirectly, support distinctive products and processes. Such resources may generate sustainable rents if ex post limits on imitability exist (e.g., Lippman \& Rumelt, 1982; Peteraf, 1993). To the extent that ex post limits on competition and imperfect resource mobility yield sustainable rents, the firm is in a better position to maintain margin and volume stability in the face of real exchange rate movements. Hence,

\section{H3: R\&D-intensity decreases foreign exchange exposure.}

Even firms with sales exclusively in their domestic market may experience economic exposure to foreign exchange rate movements due to the use of imported inputs or competition with imported goods in their industry (Hodder, 1982; Jacque, 1978: ch. 6; Shapiro, 1992: ch. 11). Opportunities for market crosssubsidization by multinational corporations operating in the same country may also hurt a purely domestic firm's competitive position when real exchange rates move. Hence, in assessing the economic exposure of a firm, it is necessary to assess not only the extent to which the firm sells its products in international markets, but also the extent to which intercountry rivalry impacts the industry. The extent of international market segmentation or integration in either input or output markets affects the economic exposure of firms in an industry (Flood \& Lessard, 1986). The extent of global market integration affects the proportion of product market cash flows nondomestic firms can contest (Luehrman, 1991).

Due to the lack of a good proxy for international integration of input markets, this study focused on integration of product markets. Industry average foreign sales to total sales was used as a proxy for the extent of international market integration. Foreign sales captures both parent export sales and sales by foreign subsidiaries of multinational corporations. A justification for using this measure is provided by Kobrin (1991) who reported a significant positive correlation $(0.617, \mathrm{p}<.01)$ between his measure of industry integration (reflecting intrafirm trade as a proportion of foreign sales) and the percentage of total industry sales generated abroad (through parent exports and affiliate sales). 
George and Schroth (1991) proposed that exposure to foreign exchange rates is positively related to the ratio of foreign sales to total sales in an industry. Our specific hypothesis regarding international product market integration is:

H4: The industry average proportion of foreign sales to total sales increases foreign exchange exposure.

\section{ESTIMATION OF CORPORATE FOREIGN EXCHANGE EXPOSURES}

\section{Analysis of Exchange Rate Data}

In order to test the four hypotheses, it was first necessary to address the estimation of corporate foreign exchange exposures. As noted earlier, one questionable assumption in previous economic exposure estimates is that a single proxy can be used to capture the variability in major foreign exchange rates. We generated a correlation matrix from time series data on major currencies and used factor analysis to determine the appropriateness of using a single currency or weighted sum of exchange rate values in estimating foreign exchange exposure. In order to determine the most pertinent exchange rates to be used in the analysis, aggregate U.S. export-import activity was calculated from 1992 OECD trade data to reveal the most significant U.S. trading partners on a bilateral basis (OECD, 1993). Table 1 presents the percentage of aggregate trade (merchandise exports plus imports) for the major U.S. trading partners. The table includes the 15 major U.S. trading partners accounting for at least $1.5 \%$ of total trade.

Put Table 1 here

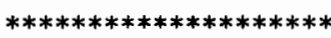

Correlations among the currencies were computed using six years (1987-1992) of monthly data on the dollar price of the twelve currencies as reported in the International Monetary Fund's International Financial Statistics CD-ROM package. The dollar price of a given foreign currency was obtained by taking the reciprocal of the foreign-denominated price of the dollar as reported in the IFS files. As indicated in the appendix (point 1), each foreign exchange rate was expressed as the real dollar value of the currency by adjusting for the monthly consumer price index in the foreign country relative to that of the U.S.. Monthly price level data were also obtained from the IFS package. Due to missing currency and/or price data, 
Taiwan, China, and Saudi Arabia were excluded from the computed correlations and factor analysis. The remaining tweive countries accounted for 67.13 percent of total U.S. trade activity in 1992 . Table 2 presents the correlations among the currencies using six years (1987-1992) of monthly data. The table indicates the presence of both positive and negative significant exchange rate correlations.

Put Table 2 here

Table 3 indicates the principal components factor analysis results for the six years of monthly real exchange rate data. Orthogonal varimax rotation generated the reported results. Loadings are indicated for the two factors with eigenvalues greater than 1.0. Bold print indicates those loadings greater than 0.60 . The reported eigenvalues and percent of variance figures pertain to the rotated factor solution. A similar two-factor solution was also obtained for the each of the three two-year $(n=24)$ subperiods in the 19871992 data, indicating factor stability over the sample period.

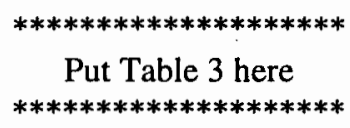

The factor structure indicates at least two exchange rate proxies should be included when modeling the economic exposure of U.S. firms. The high loadings for Belgium, France, Germany, Italy, Netherlands, and the U.K. indicate a common factor for those currencies included in the European Exchange Rate Mechanism (ERM). The remaining currencies, with the exception of Japan, have high loadings on the second factor. The low communality for the Japanese yen, just 0.242 , indicates low correlations between the yen and the two common factors. Communalities for the other currencies range from 0.794 to 0.985 . The two factors capture $83.8 \%$ of the variance in the data.

The correlation and factor analysis results do not support the assumption found in previous research on economic exposure that a single proxy can be used to capture exchange rate variability. Neither a single currency nor a single weighted sum of currencies adequately captures the variability in the exchange rate data. The correlation matrix shows that while movements in the real dollar prices of the currencies are generally positively correlated, several exchange rates exhibit significant negative correlations. Constructing a single proxy based on a positively-weighted sum of currencies overlooks the 
low or negative correlations among exchange rates. Since aggregating currencies into a single proxy is not meaningful (particularly when nominal exchange rates are used), we would assume that previous research using such proxies underestimated the impact of foreign exchange rate movements on shareholder returns.

\section{Economic Exposure Measurement Methodology}

As noted at the outset of this paper, the concept of economic exposure refers to movements in the real market value of a firm in response to real foreign exchange movements. If we let $V(t)$ be the real value of the firm in period $t$ and $\mathbf{X}(t)$ be a $(k \times 1)$ vector of real exchange rates, we can express the vector of exposure coefficients $\beta$ using the linear model:

$$
V(t)=X^{\prime}(t) \beta+\varepsilon(t), \varepsilon(t) \sim N\left(0, \sigma^{2}\right)
$$

Time series estimation of the relation expressed in equation (1) is, however, problematic. Shifts in the size of the firm over time may not reflect shareholder wealth creation. For example, dividend payments reduce firm value. Public offerings of new shares of stock increase the total market value of the firm but will only change the value of previously outstanding shares if the newly raised capital is invested in projects earning a rate of return which differs from the cost of capital. These observations indicate that using the total market value of equity as the dependent variable does not result in estimable exposure coefficients using time series data from a single firm if new shares are issued or dividends paid. For similar reasons, the use of total firm value precludes cross sectional comparison of exposure coefficients.

For estimation purposes, it is useful to specify firm value as a nonlinear function of $k$ exchange rates:

$$
V(t)=\prod_{i=1}^{k} \beta_{0} x_{i}(t)^{\beta i} \varepsilon(t)
$$

This equation can be rewritten in the log linear form:

$$
\log [V(t)]=\log \left[\beta_{0}\right]+\sum_{i=1}^{k} \beta_{i} \log \left[X_{i}(t)\right]+\log [\varepsilon(t)]
$$


Taking the derivative of equation (3) with respect to $t$, we have:

$$
[d V(t) / d t] / V(t)=\sum_{i=1}^{k} \beta_{i}\left[d X_{i}(t) / d t\right] / X_{i}(t)+\eta(t)
$$

where the error term, $\eta(t)=[d \varepsilon(t) / d t] / \varepsilon(t)$. The coefficients in this equation can be interpreted as the elasticities of firm value with respect to each of the independent variables (Glaister, 1978: 117-118) conditional on all other variables in the model.

Using discrete data, we can express the equation (4) relations in terms of the rates of change of each of the variables:

$$
R_{V}=\sum_{i=1}^{n} \beta_{i} R_{i}(t)+\eta(t)
$$

where $R_{V}(t)$ is the rate of return to shareholders in period $t$ to shareholders for a specific firm and $R_{i}$ is the rate of change of $\mathrm{X}_{\mathrm{i}}$. Unlike equation (1), equation (5) provides a basis for estimating exposure coefficients using time series data. Expressing the dependent variable as the rate of return to shareholders results in a model which is invariant to changes in the size of the firm over time. Estimated parameters from equation (5) are also comparable across organizations.

Based on the factor analysis results, two currencies were chosen for inclusion in the model of firm economic exposure to foreign exchange rate movements. The criteria for selecting currencies were to choose the currencies of the largest U.S. trading partners and to choose one currency from each of the two distinct factors reported in Table 3. On this basis, the Canadian dollar and Deutsche mark were chosen. Since the communality for the Japanese yen was small, in addition to estimating a model using just two currencies, we also estimated a three currency model including the yen in addition to the Canadian dollar and Deutsche mark. The two models were:

$$
\begin{aligned}
& R_{j}(t)=\beta_{0 j}+\beta_{1 j} R_{D M}(t)+\beta_{2 j} R_{C \$}(t)+\varepsilon_{j}(t) \\
& R_{j}(t)=\beta_{0 j}+\beta_{1 j} R_{D M}(t)+\beta_{2 j} R_{C \$}(t)+\beta_{3 j} R_{¥}(t)+\varepsilon_{j}(t)
\end{aligned}
$$

where $R_{j}(t)$ is the stock return for firm $j$ in period $t, R_{D M}(t), R_{C}(t)$, and $R_{¥}(t)$ are the percentage changes in the real values of the Deutsche mark, Canadian dollar, and Japanese yen, respectively, and $\varepsilon_{j}(t)$ is the normally distributed error term with mean zero. 
Oxelheim and Wihlborg (1987) argued that since other macroeconomic variables are correlated with exchange rate movements, failure to include them in an exposure model could result in unwarranted conclusions regarding the proportion of the variance in stock returns attributable to foreign currency movements. Hence, in addition to estimating the two exposure models using only the percentage changes in currency rates as independent variables, we also considered a macroeconomic model of corporate exposure which controlled for percentage changes in interest rates and returns to the overall stock market. The estimated two and three currency models of economic exposure were:

$$
\begin{aligned}
& R_{j}(t)=\beta_{0 j}+\beta_{1 j} R_{m}(t)+\beta_{2 j} R_{r}(t)+\beta_{3 j} R_{D M}(t)+\beta_{4 j} R_{C}(t)+\varepsilon_{j}(t) \\
& R_{j}(t)=\beta_{0 j}+\beta_{1 j} R_{m}(t)+\beta_{2 j} R_{r}(t)+\beta_{3 j} R_{D M}(t)+\beta_{4 j} R_{C}(t)+\beta_{5 j} R_{¥}(t)+\varepsilon_{j}(t)
\end{aligned}
$$

where $R_{m}(t)$ is a value-weighted market portfolio return in month $t$ and $R_{r}(t)$ is the percentage change in the U.S. prime interest rate.

The approach taken here is consistent with previous research on interest rate exposure of stock returns. Flannery and James (1984) and Sweeney and Warga (1986) controlled for movements in market returns in determining the interest rate sensitivity of stock returns. Research on foreign exchange exposure estimation has included model specifications both without (Both \& Rotenberg, 1990) and with a stock market return control variable (Amihud, 1994; Bodnar \& Gentry, 1993). Jorion (1990) estimated models of foreign exchange rate sensitivity both with and without a control for stock market returns.

For equations (6) through (9) economic exposure to foreign exchange rate movements is indicated by rejection of the hypothesis that the foreign exchange rate coefficients in the model are all equal to zero. Hence, the appropriate test for aggregate economic exposure to foreign exchange rate movements is an $F$ test rather than $t$ tests for the effects of each of the individual currencies (Kmenta, 1986: 248). For models (8) and (9) the F test measures the impact of exchange rate fluctuations while controlling for market portfolio returns and interest rate changes. As such, the $\mathrm{F}$ tests using the macroeconomic models provide more conservative tests for the significance of economic exposure to foreign exchange rate movements than do the models ( 6 and 7 ) excluding market return and interest rate variables. 
Nominal monthly holding period stock returns were obtained from the Center for Research in Security Prices (CRSP) data files. Holding period returns were obtained for all manufacturing firms--SIC codes in the range 3000-3999. Firms which had any missing returns for the five-year period 1988-1992 were omitted from the dataset, providing a total of 249 firms. As explained in the appendix (point 2),

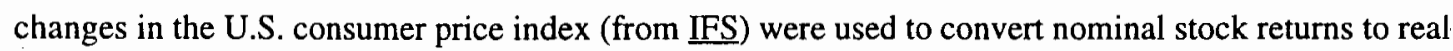
returns.

The CRSP data files provided value-weighted market portfolio returns, which include all distributions and exclude American Depository Receipts (ADRs). U.S. consumer price levels obtained from the IFS package were used to deflate the monthly value-weighted market portfolio returns to real returns (see appendix point 2).

The IFS package also provided the monthly U.S. prime interest rate data. The nominal U.S. prime interest rate was converted to its real counterpart, with the percentage change in the real U.S. prime interest rate being the regressor used in estimating equations (8) and (9) (see appendix point 3).

\section{Economic Exposure Measurement Results}

Ordinary least squares regression was used to estimate models (6) through (9). Table 4 indicates the percentage of firms with significant $(p<.05 ; p<.10)$ exposures to foreign exchange rates for each model. For models (8) and (9), the percentage of firms with significant exposures to the market return and interest rate are also indicated. Since the models were estimated using time series data, error terms may exhibit autocorrelation. Table 4 indicates the proportion of firms with Durbin-Watson test statistics falling below the lower bound (i.e., reject the hypothesis of positive autocorrelation), above the upper bound (i.e., do not reject the hypothesis of positive autocorrelation), and in the inconclusive range between the lower and upper bound. The results do not give reason to be concerned about autocorrelated disturbances.

Put Table 4 here 
Table 4 indicates that roughly ten percent of firms are exposed to foreign exchange movements at the five percent significance level and twenty percent of the sample is exposed to foreign exchange movements at the ten percent significance level. The proportion of firms exposed to foreign exchange rate movements is generally consistent across the four models. While the proportion of firms with significant foreign exchange exposure is slightly less than the proportion exposed to interest rate movements using the .05 criterion, the proportions are comparable at the .10 significance level.

These results contrast with those of previous research assessing exchange rate exposure. As noted earlier, Jorion (1990) found just 15 of 287 firms (5.23\%) were significantly exposed to a trade-weighted exchange rate average (MERM) for the period 1981-1987. Since his decision criteria was the .05 level, Jorion's results reflect a random phenomenon. In their investigation of 156 Canadian firms, Booth and Rotenberg (1990) found that 67 percent of firms were significantly exposed at the five percent level (onetail). Their model used the nominal U.S.-Canadian exchange rate for the period 1979-1983.

Jorion's (1990) low proportion of firms with significant exchange rate exposures can be attributed to two methodological shortcomings. First, as demonstrated by the earlier factor analysis results, Jorion's use of a single trade-weighted exchange rate proxy derived from weights in the 1977 Multilateral Exchange Rate Model (MERM) is inappropriate. Second, Jorion used nominal exchange rate and stock return data rather than inflation-adjusted data. By contrast, firm economic exposure is defined in terms of changes in real shareholder returns in response to real exchange rate changes. It is not at all clear what is being measured when nominal exchange rates are aggregated using the same weights in different time periods. Given these shortcomings, it is not surprising that Jorion reported just $5 \%$ of the firms had significant exposure at the .05 level--providing no evidence of a systematic relation between exchange rate movements and shareholder returns.

While Booth and Rotenberg (1990) did not include controls for market returns or interest rate changes in their model of foreign exchange rate exposure, the results presented in Table 4 indicate that the exclusion of macroeconomic control variables does not reconcile our findings with theirs. They speculated that the high proportion (67\%) of significant negative exposures of Canadian firms to movements in the nominal spot Canadian dollar price of the U.S. dollar may be due to widespread reliance on U.S. dollar- 
denominated debt financing. Hence, their sample may not be comparable with our sample of U.S.

manufacturing firms.

\section{TESTS OF HYPOTHESES}

\section{Regression Model}

The four hypotheses concerning strategy and industry influences on economic exposure were tested using cross-sectional Ordinary Least Squares regression. We estimated four different regression equations differing only in their dependent variables. The four dependent variables, $F_{i}(i=6, \ldots, 9)$, were the F-values of the multivariate tests for the significance of the foreign exchange rate coefficients in the four economic exposure models presented earlier (equations 6 through 9). ${ }^{1}$ The model took the form:

$$
F_{i}=\gamma_{0}+\gamma_{1} \mathrm{EXP}+\gamma_{2} \mathrm{FDI}+\gamma_{3} \mathrm{R} \& \mathrm{D}+\gamma_{4} \mathrm{IND}+\varepsilon
$$

Estimates of the model coefficients $\left(\gamma_{1}\right.$ through $\left.\gamma_{4}\right)$ provide tests for hypotheses 1 through 4 discussed earlier. EXP represents the firm's exports to total sales. FDI is the firm's identifiable foreign assets divided by total assets. R\&D indicates the firm's R\&D expenditures to total sales. Each of these variables was computed as the average for the five-year period 1988-1992. IND is the average foreign sales to total sales for the industry at the two-digit SIC code level. IND was calculated by first determining the average foreign sales to total sales for each firm for the period 1988-1992, and then taking the average for all firms in a given two-digit SIC code based on a combined dataset of 211 firms. Each two-digit SIC code contained at least six firms in this data set. The Compustat CD-ROM package provided data on total and foreign assets, total and foreign sales, exports, and R\&D expenditures.

The choice of dependent variable in the regression models contrasts with that of previous research. Previous studies (Bodnar \& Gentry, 1993; Booth \& Rotenberg, 1990; Jorion, 1990) sought to explain the sign of firms' exposure coefficients rather than their magnitude. Such an approach makes unwarranted assumptions about the generalizability of the sign of exposure coefficients across firms. For example, no general relation should exist between the ratio of foreign assets to total assets and the sign of the foreign exchange exposure coefficient if some firms use their subsidiaries to access inputs while others use them as sales branches. However, if the option theory argument holds, we may observe a reduction in the absolute 
value of the exposure in either case. Similarly, R\&D intensity may reduce the absolute value of the exposure coefficients without reversing their signs. Following this reasoning, our approach looked at the magnitude of exposures (as reflected in multivariate F statistics) and avoided unwarranted assumptions regarding the direction of exposures.

Due to missing data, the final combined data set contained complete data for 80 manufacturing firms. The 80 firms generally had a slightly lower percentage of firms with significant foreign exchange rate exposures than the full 249 -firm sample. At a five percent significance level, 8.8 percent were exposed for equation (6), 6.3 percent for equation (7), 8.8 percent for equation (8), and 11.3 percent for equation (9).

\section{Results}

Table 5 presents descriptive statistics and a correlation matrix for the regression variables. For the period 1988-1992 the mean level of export activity was 11.8 percent of total sales, the average firm committed 20.1 percent of its assets to foreign operations, and the mean ratio of $R \& D$ to total sales was 4.3 percent. Industry foreign sales intensity, an indicator of the extent of global industry integration, ranged from less than 10 percent to over 30 percent among the two-digit SIC manufacturing industries. Consistent with theories of the MNE as agents for technology transfer, R\&D intensity was positively correlated with industry foreign sales intensity. The bivariate correlations support the hypothesized negative relation between FDI-intensity and exposure to foreign exchange rates.

Put Table 5 here

$* * * * * * * * * * * * * * * * * * * *$

Diagnostics from initial estimates of the four regression models indicated a small number of outlier observations. Outliers with studentized residuals exceeding 2.0 were eliminated. Table 6 provides the results for the four regression models after eliminating outliers.

Put Table 6 here

$* * * * * * * * * * * * * * * * * * * * *$ 
The results proved quite consistent using the four aiternative proxies for corporate economic exposure to foreign exchange rates. The most substantive finding was the significant negative coefficient for FDI. This finding supports the hypothesis (H2) that foreign market participation through direct investment reduces firms' exposures to exchange rate movements.

No support was found for the other three hypotheses. For the sample data the export-intensity and R\&D-intensity strategy variables did not exhibit significant relations with economic exposure to foreign exchange rates. Contrary to the contention found in previous research, export-intensity does not increase foreign exchange exposure. R\&D intensity, a proxy for differentiation-based generic competitive strategies, does not reduce foreign exchange exposure. It therefore appears that investments in R\&D-based "higherorder" advantages do not necessarily enhance firms' abilities to shield themselves from exchange rate fluctuations. This result is not congruent with Porter's (1990) assertion that differentiation strategies provide greater sustainable competitive advantage relative to cost leadership strategies in the presence of foreign exchange rate volatility.

The proxy for industry integration, industry average ratio of foreign sales to total sales, had insignificant and contradictory signs across the four models. Using this proxy for international product market integration, there is no evidence for the contention that intercountry rivalry at the industry level increases firms' economic exposures to foreign exchange rate movements.

\section{DISCUSSION}

A primary contribution of this study was the attention given to appropriate model specification in estimating economic exposure to foreign exchange rate movements. Unlike previous research, this study challenged the appropriateness of using a single currency or a weighted sum of currencies as a proxy for foreign exchange rates. The factor analysis results indicated the use of two or three currencies would capture much of the variance in the exchange rates of major U.S. trading partners.

Using a multivariate model to estimate exchange rate exposure coefficients, the results indicated roughly 20 percent of manufacturing firms had significant economic exposures to foreign exchange movements at the .10 significance level, and roughly 10 percent had significant exposures at the .05 level. 
The inclusion or exclusion of macroeconomic control variables did not materially alter the proportion of "exposed" firms. These findings indicate current financial and strategic hedging practices do not eliminate economic exposures to foreign exchange rate movements for many U.S. firms. These results contrast with Jorion's (1990) finding that the proportion of U.S. multinational firms with significant exposures at the .05 level was just 5.23 percent--indicating no systematic relation between exchange rate movements and shareholder returns. Jorion's use of a weighted sum of nominal exchange rates is not easily interpreted and results in underestimating the actual proportion of firms with significant economic exposure.

The most prominent result regarding the impacts of firm strategy and industry structure on economic exposure was the significant negative effect of foreign direct investment. This finding supports the proposition that a multinational presence offers strategic options unavailable to purely domestic firms (Campa, 1994; Kogut, 1983; Kogut \& Kulatilaka, 1994; Lessard \& Lightstone, 1986; Lessard \& Nohria, 1990). The empirical results suggest that international strategic options for sourcing inputs and locating manufacturing, marketing, and other activities reduce the volatility of shareholder returns.

Previous research on economic exposure has not considered the possible contrasting effects associated with direct investment and exports as alternative foreign market entry strategies. Whereas FDI had a significant negative effect on foreign exchange exposure, export-intensity did not significantly impact exposures. The contrasting effects of FDI and exports reveals that economic exposure is sensitive to the choice between these two foreign market entry modes.

The insignificance of our proxy for product differentiation--R\&D intensity--indicates firms' investments in "higher-order advantages" (Porter, 1990) provides no reduction in the risk associated with exchange rate fluctuations. In order to capture the influence of marketing-based product differentiation, we also proxied differentiation using advertising intensity. Our results (not reported here) indicated that the advertising intensity variable was similarly insignificant in all four models. Future work might employ more sophisticated proxies which directly measure switching costs and rivals' opportunities for imitation to examine if currency pass-through opportunities are shaped by firm-specific advantages.

Apart from the conclusions regarding the effects of firms' strategies, the empirical results also suggest that the extent to which product markets are integrated across national borders has no significant 
impact on manufacturing firms' exposures to foreign exchange rate movements. This study examined the effects of industry integration at the product market level. Future research might investigate the role of industry integration in input markets and consider alternative proxies for cross-border product market integration.

The results discussed above pertain to the economic exposures of manufacturing enterprises during the period 1988-1992. The focus on manufacturing firms leaves open the question of the extent to which this study's findings generalize to other industries. Future research might explore whether the hypotheses developed here apply in other industries (e.g., services) and the extent to which our empirical results hold for non-manufacturing firms.

It should also be emphasized that our model provides a cross-sectional assessment of the impact of firm-specific strategy variables and industry integration on economic exposure. An important extension of this research would be to examine changes in firms' exposures over time using a longitudinal research design. In addition to looking at how changes in strategy affect economic exposures, such a study could also look at the reverse relationship, namely, how firms' respond to economic exposures. Possible responses might include changes in financial hedging policies as well as strategic actions. 


\section{ENDNOTES}

${ }^{l}$ We also considered estimating the model using a cross-sectional binary logit mode, where the response obtains a value of one if the F-test for the economic exposure model (equations 6 through 9) is significant and zero otherwise. Because of the small number of exposed firms, the logit results were not robust to the choice among the four economic exposure models nor between the .05 and .10 levels for determining whether the $F$ values were significant. By contrast, the coefficient signs and magnitudes were quite stable using the OLS regression model treating the $\mathrm{F}$ values as continuous variables. 


\section{REFERENCES}

Adler, M. \& Dumas, B. 1984. Exposure to currency risk: Definition and measurement. Financial Management, 13 (2): 41-50.

Amihud, Yakov. 1994. Exchange rates and the valuation of equity shares. In Yakov Amihud and Richard Levich (Eds.) Exchange rates and corporate performance: 49-59. Burr Ridge, Illinois: Irwin.

Batten, J., Mellor, R. \& Wan, V. 1993. Foreign exchange risk management practices and products used by Australian firms. Journal of International Business Studies, 23: 557-573.

Bodnar, Gordon M. \& Gentry, William M. 1993. Exchange rate exposure and industry characteristics: Evidence from Canada, Japan, and the USA. Journal of International Money and Finance, 12: 29-45.

Booth, L. \& Rotenberg, W. 1990. Assessing foreign exchange exposure: Theory and application using Canadian firms. Journal of International Financial Management and Accounting, 2: 1-22.

Brealey, Richard A. \& Myers, Stewart C. 1991. Principals of corporate finance. New York: McGraw-Hill.

Campa, J. M. 1994. Multinational investment under uncertainty in the chemical processing industries. Journal of International Business Studies, 25: 557-578.

Ceglowski, J. 1989. Dollar depreciation and U.S. industry performance. Journal of International Money and Finance, 8: 233-251.

Dixit, Avinash. 1989. Hysteresis, import penetration, and exchange rate pass-through. Quarterly Journal of Economics, 104: 205-228.

Dufey, G. 1972. Corporate finance and exchange rate variations. Financial Management, 1 (2): 51-57.

Flannery, M. J. \& James, C. M. 1984. The effect of interest rate changes on the common stock returns of financial institutions. Journal of Finance, 39: 1141-1153.

Froot, K. A. \& Klemperer, P. D. 1989. Exchange rate pass-through when market share matters. American Economic Review, 79: 637-654.

Garner, C. K. \& Shapiro, A. C. 1984. A practical method of assessing foreign exchange risk. Midland Corporate Finance Journal, 2 (3): 6-17.

George, A. M. \& Schroth, C. W. 1991. Managing foreign exchange for competitive advantage. Sloan Management Review, Winter: 105-116.

Glaister, S. 1978. Mathematical methods for economists (Revised ed.). Oxford, England: Basil Blackwell.

Hodder, J. E. 1982. Exposure to exchange-rate movements. Journal of International Economics, 13: 375386.

Jacque, Laurent L. 1978. Management of foreign exchange risk. Lexington, Massachusetts: Lexington Books.

Jorion, Philippe. 1990. The exchange rate exposure of U.S. multinationals. Journal of Business, 63: 331345. 
Kester, W. C. \& Luehrman, T. A. 1989. Are we feeling more competitive yet? The exchange rate gambit. Sloan Management Review, Winter: 19-28.

Kmenta, Jan. 1986. Elements of econometrics (2nd ed.). New York: Macmillan Publishing.

Knetter, M. M. 1989. Price discrimination by U.S. and German exporters. American Economic Review, 79: 198-210.

Kobrin, S. J. 1991. An empirical analysis of the determinants of global integration. Strategic Management Journal, $12(\mathrm{~S}): 17-31$.

Kogut, Bruce. 1983. Foreign direct investment as a sequential process. In Kindleberger, C. P. \& Audretsch, D. B. (Eds.) The multinational corporation in the 1980s: 38-56. Cambridge, Massachusetts: MIT Press.

Kogut, B., \& Kulatilaka, N. 1994. Operating flexibility, global manufacturing, and the option value of a multinational network. Management Science, 40: 123-139.

Kohn, K. 1990. Are you ready for economic-risk management? Institutional Investor, 24 (11): 203-207.

Khoury, S. J., Nickerson, D., \& Sadanand, V. 1991. Exchange rate uncertainty and precommitment in symmetric duopoly: A new theory of multinational production. In S. J. Khoury (Ed.) Recent developments in international banking, vol. 4-5: 461-494. Amsterdam, Netherlands: Elsevier Science Publishers.

Krugman, P. 1987. Pricing to market when exchange rate changes. In Richardson, J. D. (Ed.) Real-financial linkages among open economies: 49-70. Cambridge, Massachusetts: MIT Press.

Lessard, Donald R. \& Lightstone, John B. 1986. Volatile exchange rates can put operations at risk. Harvard Business Review, July-August: 107-114.

Lessard, D. R. \& Nohria, N. 1990. Rediscovering functions in the MNC: The role of expertise in firms' responses to shifting exchange rates. In Bartlett, C. A., Doz, Y, \& Hedlund, G. (Eds.) Managing the global firm: 186-212. New York: Routledge.

Lewent, J. C. \& Kearney, J. A. 1990. Identifying, measuring, and hedging currency risk at Merck. Continental Bank Journal of Applied Corporate Finance, 2 (4): 19-28.

Lippman, S. A. \& Rumelt, R. P. 1982. Uncertain imitability: An analysis of interfirm differences in efficiency under competition. Bell Journal of Economics, 13: 418-438.

Luehrman, T. A. 1990. The exchange rate exposure of a global competitor. Journal of International Business Studies, 21: 225-242.

Luehrman, T. A. 1991. Exchange rate changes and the distribution of industry value. Journal of International Business Studies, 22: 619-649.

Mann, C. L. 1986. Prices, profit margins, and exchange rates. Federal Reserve Bulletin, June: 366-379.

Organization for Economic Cooperation and Development (OECD). 1993. Monthly statistics of foreign trade, September. Paris: OECD.

Oxelheim, L. \& Wihlborg, C. 1987. Macroeconomic uncertainty: International risks and opportunities for the corporation. New York: John Wiley. 
Peteraf, M. A. 1993. The cornerstones of competitive advantage: A resource-based view. Strategic Management Journal, 14: 179-191.

Porter, Michael E. 1990. The competitive advantage of nations. New York: Free Press.

Rawls, S. W. \& Smithson, C. W. 1990. Strategic risk management. Journal of Applied Corporate Finance, 2 (4): 6-18.

SAS. 1990. SAS/STAT user's guide, Version 6. Cary, North Carolina: SAS Institute Inc.

Shapiro, A. C. 1975. Exchange rate changes, inflation, and the value of the multinational corporation. Journal of Finance, 30: 485-502.

Shapiro, Alan C. 1992. Multinational financial management (4th ed.). Boston: Allyn and Bacon.

Sundaram, A. K. \& Mishra, V. 1991. Currency movements and corporate pricing strategy. In S. J. Khoury (Ed.) Recent developments in international banking, vol. 4-5: 203-241. Amsterdam, Netheriands: Elsevier Science Publishers.

Sweeney, R. J. \& Warga, A. D. 1986. The pricing of interest-rate risk: Evidence from the stock market. Journal of Finance, $41: 393-410$. 


\begin{abstract}
APPENDIX
1. The real dollar price of a currency at time $t$ is given by: $e^{\prime}(t)=e_{t}\left[P_{f}(t) / P_{h}(t)\right]$, where $e_{t}$ is the nominal dollar price of the currency at time $t, \mathrm{P}_{\mathrm{f}}(\mathrm{t})$ is the foreign country's consumer price level at time $t$, and $\mathrm{P}_{\mathrm{h}}(\mathrm{t})$ is the U.S. consumer price level at time $t$ (Shapiro, 1992: 155).

2. Real stock returns $\left(R_{j}\right)$ and market returns $\left(R_{m}\right)$ are given by: $R_{j}\left(\right.$ or $\left.R_{m}\right)=\left[\left(1+r_{n}\right) /\left(1+i_{h}\right)\right]-1$, where $r_{n}$ is the nominal stock (or market hoiding period return), and $i_{h}$ is the inflation rate given by the percentage change in the U.S. consumer price level (Brealey \& Myers, 1991: 559).

3. The real U.S. prime interest rate is given by: $r_{r}=\left[\left(1+r_{n}\right) /\left(1+i_{h}\right)\right]-1$, where $r_{n}$ is the nominal U.S. prime interest rate, and $i_{h}$ is the inflation rate given by the percentage change in the U.S. consumer price level (Brealey \& Myers, 1991: 559). The percentage change in the real U.S. prime interest rate is given by: $R_{r}=\left[r_{r}(t)-r_{r}(t-1)\right] / r_{r}(t-1)$
\end{abstract}


TABLE 1

1992 Aggregate US Trading Activity

\begin{tabular}{ll}
\hline Country & Percent of Aggregate US Trade \\
\hline Canada & $19.28 \%$ \\
Japan & 14.74 \\
Mexico & 7.74 \\
Germany & 5.11 \\
United Kingdom & 4.39 \\
Taiwan & 4.07 \\
China & 3.39 \\
South Korea & 3.20 \\
France & 3.00 \\
Italy & 2.15 \\
Singapore & 2.14 \\
Netherlands & 1.94 \\
Hong Kong & 1.93 \\
Saudi Arabia & 1.79 \\
Belgium & 1.51 \\
& \\
15-Country Total & $76.38 \%$ \\
\hline
\end{tabular}

Source: OECD (1993: 52-53) 
TABLE 2

Correlations Among Real Foreign Exchange Rates $(1987-1992)^{a}$

\begin{tabular}{|c|c|c|c|c|c|c|c|c|c|c|c|}
\hline Country & 1 & 2 & 3 & 4 & 5 & 6 & 7 & 8 & 9 & 10 & 11 \\
\hline 1. Belgium & & & & & & & & & & & \\
\hline 2. Canada & -.063 & & & & & & & & & & \\
\hline 3. France & $.994 * * *$ & -.064 & & & & & & & & & \\
\hline 4. Germany & $.988 * * *$ & -.147 & $.987 * * *$ & & & & & & & & \\
\hline 5. Hong Kong & $.415^{* * *}$ & $.476 * * *$ & $.381 * *$ & $.376 * *$ & & & & & & & \\
\hline 6. Italy & $.740^{* * *}$ & $.359 * *$ & $.854 * * *$ & $.812 * * *$ & $.585 * * *$ & & & & & & \\
\hline 7. Japan & $.211 \dagger$ & $-.358 * *$ & $.217 \dagger$ & $.312 * *$ & -.125 & -.018 & & & & & \\
\hline 8. Mexico & $.279^{*}$ & $.646 * * *$ & $.258^{*}$ & $.242^{*}$ & $.935 * * *$ & $.511 * * *$ & -.083 & & & & \\
\hline 9. Netherlands & $.965 * * *$ & $-.253^{*}$ & $.964 * * *$ & $.987^{* * *}$ & $.265^{*}$ & $.740 * * *$ & $.387 * * *$ & .125 & & & \\
\hline 10.Singapore & $.620 * * *$ & $.423 * * *$ & $.589 * * *$ & $.584 * * *$ & $.950 * * *$ & $.756^{* * *}$ & .015 & $.876^{* * *}$ & $.485^{* * *}$ & & \\
\hline 11.S. Korea & -.124 & $.882 * * *$ & -.115 & -.176 & $.580 * * *$ & $.223 \dagger$ & $-.261^{*}$ & $.777 * * *$ & $-.293^{*}$ & $.471^{* * *}$ & \\
\hline 12.U.K. & $.704 * * *$ & $.518^{* * *}$ & $.710^{* * *}$ & $.656^{* * *}$ & $.563 * * *$ & $.893 * * *$ & .138 & $.605 * * *$ & $.584^{* * *}$ & $.722 * * *$ & $.425 * * *$ \\
\hline
\end{tabular}

$$
\begin{array}{rl}
a_{+} & p<.10 \\
* & p<.05 \\
* * & p<.01 \\
* * * & p<.001
\end{array}
$$


TABLE 3

Varimax Rotated Factor Pattern

$(1987-1992)^{b}$

\begin{tabular}{llll}
\hline Country & Factor One & Factor Two & Communalities \\
\hline Belgium & $\mathbf{0 . 9 8 4}$ & 0.074 & 0.973 \\
Canada & -0.148 & $\mathbf{0 . 8 8 0}$ & 0.796 \\
France & $\mathbf{0 . 9 8 1}$ & 0.060 & 0.965 \\
Germany & $\mathbf{0 . 9 9 3}$ & 0.001 & 0.985 \\
Hong Kong & 0.379 & $\mathbf{0 . 8 0 6}$ & 0.794 \\
Italy & $\mathbf{0 . 8 2 5}$ & 0.448 & 0.882 \\
Japan & 0.351 & -0.344 & 0.242 \\
Mexico & 0.242 & $\mathbf{0 . 9 0 9}$ & 0.884 \\
Netherlands & $\mathbf{0 . 9 8 4}$ & -0.130 & 0.985 \\
Singapore & 0.598 & $\mathbf{0 . 7 2 0}$ & 0.876 \\
S. Korea & -0.195 & $\mathbf{0 . 9 1 5}$ & 0.876 \\
U.K. & $\mathbf{0 . 6 9 1}$ & 0.565 & 0.796 \\
& & & \\
Eigenvalue & 5.784 & 4.270 & \\
\% of Variance & 48.198 & 35.580 & \\
Cum. \% of Variance & 48.198 & 83.778 & \\
\hline
\end{tabular}

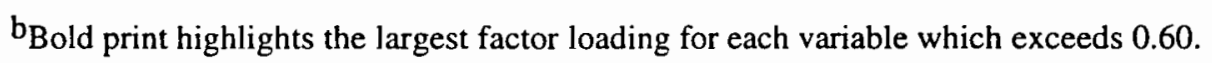


TABLE 4

Estimates of Economic Exposure

to Foreign Exchange Rate Movements

$\begin{array}{lllll} & \text { Model (6) } & \text { Model (7) } & \underline{\text { Model (8) }} & \text { Model (9) } \\ \text { FX Rates Represented } & \begin{array}{l}\text { Canada } \\ \text { Germany }\end{array} & \begin{array}{l}\text { Canada } \\ \text { Germany } \\ \text { Japan }\end{array} & \begin{array}{l}\text { Canada } \\ \text { Germany }\end{array} & \begin{array}{l}\text { Canada } \\ \text { Germany } \\ \text { Japan }\end{array} \\ \text { Control Variables } & \text { None } & \text { None } & \text { Market Return } & \text { Market Return } \\ & & & \text { US Prime Rate } & \text { US Prime Rate }\end{array}$

Percent Significant $(\alpha=.05)$ :

$\begin{array}{lllll}\text { FX Rates (F-test) } & 12.0 \% & 8.8 \% & 11.6 \% & 9.6 \% \\ \text { Interest Rate (t-test) } & \text { N.A. } & \text { N.A. } & 14.5 & 14.5 \\ \text { Market Return (t-test) } & \text { N.A. } & \text { N.A. } & 79.5 & 78.7\end{array}$

Percent Significant $(\alpha=.10)$ :

$\begin{array}{lllll}\text { FX Rates (F-test) } & 20.9 \% & 20.1 \% & 20.5 \% & 17.3 \% \\ \text { Interest Rate (t-test) } & \text { N.A. } & \text { N.A. } & 18.9 & 18.9 \\ \text { Market Return (t-test) } & \text { N.A. } & \text { N.A. } & 83.9 & 84.7\end{array}$

Durbin-Watson Test for Positive Autocorrelation:

$\begin{array}{lllll}\text { Reject } & 82.7 \% & 82.3 \% & 84.7 \% & 85.5 \% \\ \text { Inconclusive } & 17.3 & 17.7 & 15.3 & 14.5 \\ \text { Do Not Reject } & 0 & 0 & 0 & 0\end{array}$

$\mathrm{N}$

249

249

249

249 
TABLE 5

Descriptive Statistics and Correlation Matrix

Descriptive Statistics $(\mathrm{N}=80)$

\begin{tabular}{lllll}
\hline Variable & Mean & Std. Deviation & Minimum & Maximum \\
\hline F1 & 1.458 & 1.486 & 0.010 & 7.409 \\
F2 & 1.379 & 1.370 & 0.029 & 8.025 \\
F3 & 1.407 & 1.069 & 0.010 & 5.519 \\
F4 & 1.342 & 1.024 & 0.020 & 6.091 \\
EXP & 0.118 & 0.111 & 0.010 & 0.750 \\
FDI & 0.201 & 0.149 & 0 & 0.660 \\
R\&D & 0.043 & 0.036 & 0.001 & 0.167 \\
IND & 0.233 & 0.059 & 0.098 & 0.320 \\
\hline
\end{tabular}

Correlation Matrix ${ }^{\mathrm{c}}$

\begin{tabular}{llllllll}
\hline Variable & $(1)$ & $(2)$ & $(3)$ & $(4)$ & $(5)$ & $(6)$ & (7) \\
\hline 1. F1 & & & & & & & \\
2. F2 & $0.889^{* * *}$ & & & & & & \\
3. F3 & $0.890^{* * *}$ & $0.778^{* * *}$ & & & & & \\
4. F4 & $0.765^{* * *}$ & $0.862^{* * *}$ & $0.885^{* * *}$ & & & & \\
5. EXP & -0.032 & -0.017 & -0.074 & -0.043 & & & \\
6. FDI & -0.132 & $-0.234^{*}$ & $-0.212 \dagger$ & $-0.321^{* *}$ & -0.155 & & \\
7. R\&D & 0.134 & 0.059 & 0.136 & 0.010 & 0.184 & 0.149 & \\
8. IND & 0.058 & -0.004 & 0.052 & -0.025 & $0.215 \dagger$ & 0.048 & $0.326^{* *}$ \\
\hline
\end{tabular}

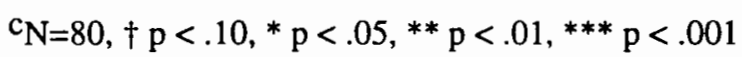

Key to Variable Names:

$F 6=F$ value for the multivariate test of significance for exchange rate coefficients (equation 6)

$\mathrm{F} 7=\mathrm{F}$ value for the multivariate test of significance for exchange rate coefficients (equation 7)

$\mathrm{F} 8=\mathrm{F}$ value for the multivariate test of significance for exchange rate coefficients (equation 8)

F9 $=\mathrm{F}$ value for the multivariate test of significance for exchange rate coefficients (equation 9)

EXP $=$ firm exports divided by total sales

FDI $=$ firm foreign assets divided by total assets

$R \& D=$ firm $R \& D$ expenditures divided by total sales

IND $=$ industry average foreign sales divided by total sales 
TABLE 6

\section{Results of OLS Regression Models ${ }^{d}$}

\begin{tabular}{|c|c|c|c|}
\hline Dependent Variable: & $\begin{array}{l}\mathrm{F} \text { from Eqn. (6) } \\
\text { (for } \mathrm{H}_{\mathrm{o}}: \beta_{1}=\beta_{2}=0 \text { ) }\end{array}$ & $\begin{array}{c}\text { F' from Eqn. (7) } \\
\text { (for } \mathrm{H}_{\mathrm{o}}: \beta_{1}=\beta_{2}=\beta_{3}=0 \text { ) }\end{array}$ & $\begin{array}{c}F \text { from Eqn. (8) } \\
\text { (for } \mathrm{H}_{\mathrm{o}}: \beta_{3}=\beta_{4}=0 \text { ) }\end{array}$ \\
\hline
\end{tabular}

Explanatory

Variables:

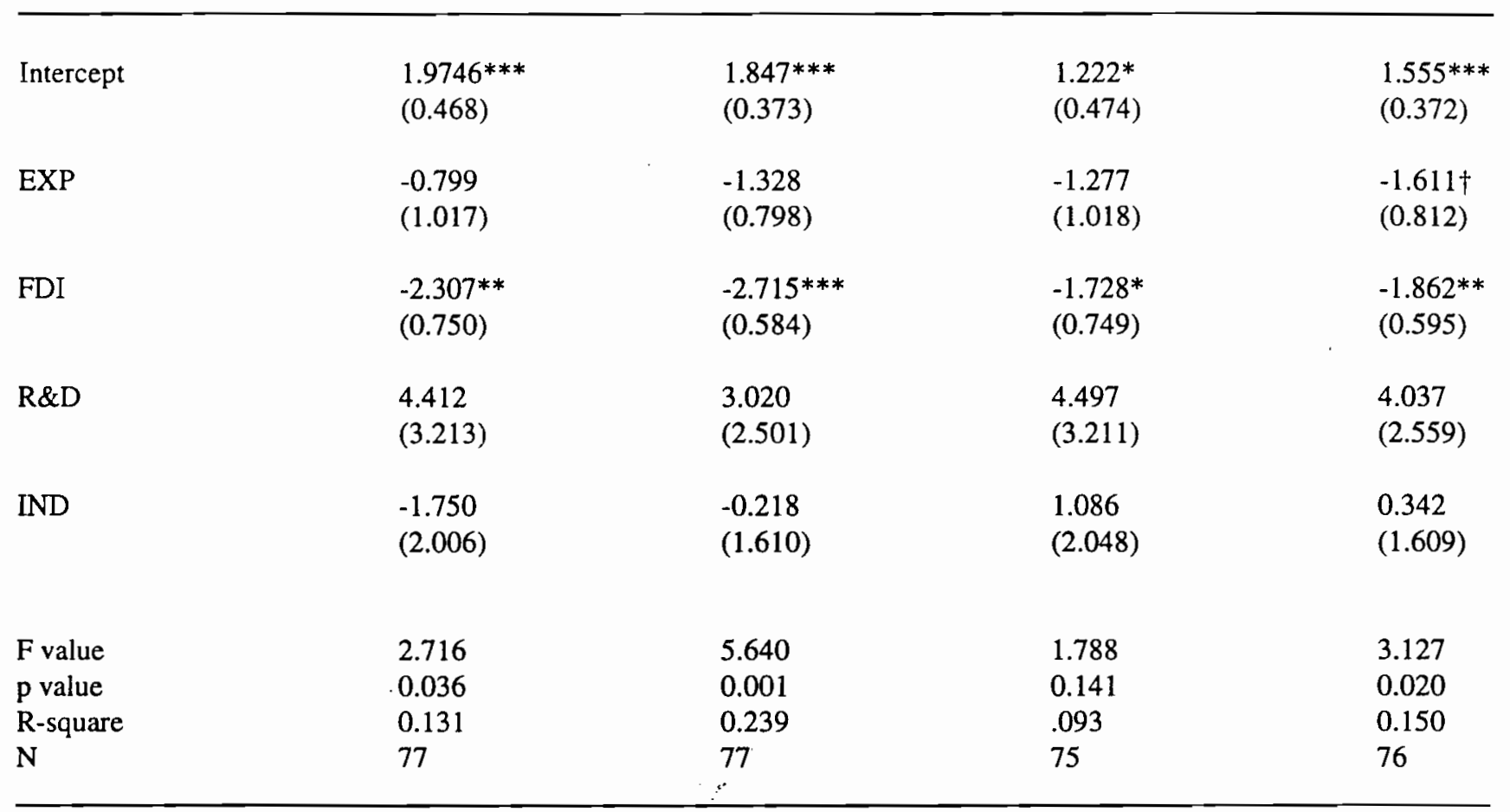

d Standard errors appear in parentheses.

$\dagger \mathrm{p}<.10$

* $p<.05$

** $\quad \mathrm{p}<.01$

$* * * \quad p<.001$ 
No. 93-101 Gordon M. Phillips, Robert J. Weiner

"Information and Normal Backwardation as Determinants of Trading Performance: Evidence from the North-Sea Oil Forward Market." 1994. The Economic Journal.

No. 93-102 Stephen R. Goldberg, Frank L. Heflin

"The Association Between the Level of International Diversification and Risk"

No. 93-103 John A. Carlson

"Risk Aversion, Foreign Exchange Speculation and Gambler's Ruin"

No. 93-104 John A. Carlson, Aasim M. Husain, Jeffrey A. Zimmerman

"Penalties and Exclusion in the Rescheduling and Forgiveness of International Loans"

No. 93-105 Kent D. Miller

"Industry and Country Effects on Manager's Perceptions of Environmental Uncertainties."

1993. Journal of International Business Studies, 24: 693-714.

No. 93-106 Stephen R. Goldberg and Joseph H. Godwin

"Foreign Currency Translation Under Two Cases-Integrated and Isolated Economies"

No. 93-107 Kent D. Miller

"A Comparison of Managers' Uncertainty Perceptions and Country Risk Indices"

No. 93-108 Jon D. Haveman

"The Effect of Trade Induced Displacement on Unemployment and Wages"

No. 93-109 Jon D. Haveman

"Some Welfare Effects of Dynamic Customs Union Formation"

No. 93-110 John A. Carlson, Insook Kim

"Central Banks' Expected Profits From Intervention

If you would like to request copies of specific papers, please contact the Center for International Business Education and Research, Purdue University, Krannert School of Management, West Lafayette, IN 47907.

(Phone: 317/494-4463 or FAX: 317/494-9658) 
No. 94-001

No. 94-002

No. 94-003

No. 94-004

No. 94-005

No. 94-006

No. 94-007

No. 94-008

No. 94-009

No. 94-010

No. 94-011

No. 94-012

No. 94-013

No. 94-014

No. 94-015

No. 94-016

No. 94-017
Casper G. De Vries, Phillip A. Stork, Kees G. Koedijk

"Between Realignments and Intervention: The Belgian Franc in the European Monetary System"

Casper G. de Vries, K. U. Leuven

"Stylized Facts of Nominal Exchange Rate Returns"

Kent D. Miller

"Operational Flexibility Responses to Environmental Uncertainties"

Kent D. Miller

"Economic Exposure and Integrated Risk Management"

Kent D. Miller

"Diversification Responses to Environmental Uncertainties"

John M. Hannon, Ing-Chung Huang, Bih-Shiaw Jaw

"International Human Resource Strategy and Its Determinants: The Case of Multinationals and Their Subsidiaries in Taiwan"

John M. Hannon, Ing-Chung Huang, Bih-Shiaw Jaw

"International Human Resource Strategy andControl: The Case of Multinationals and Their Subsidiaries"

John M. Hannon, Yoko Sano

"Customer-Driven Human Resource Policies and Practices in Japan"

John A. Carlson, Insook Kim

"Leaning Against the Wind: Do Central Banks Necessarily Lose?"

John A. Carlson, David W. Schodt

"Beyond the Lecture: Case Teaching and the Learning of Economic Theory"

Alok R. Chaturvedi, Hemant K. Jain, Derek L. Nazareth

"Key Information Systems Management Issues in Developing Countries: Differences in the Indian and US Contexts"

Jon Haveman,

The Influence of Changing Trade Patterns on Displacements of Labor

Stephen Goldberg

Financial Reporting for Foreign Exchange Derivatives

Charles Noussair, Charles Plott, Raymond Riezman

Una investigacion experimental sobre la estructura del comercia interncional (Spanish Version)

Translated: An Experimental Investigation About the Structure of International Commerce

Marie Thursby, Richard Jensen

Patent Races, Product Standards, and International Competition

Kent D. Miller, Jeffrey J. Reuer

Firm Strategy and Economic Exposure to Foreign Exchange Rate Movements

John Hannon, Yoko Sano

The Determinants of Corporate Attractiveness in Japan 
No. 94-018 John Hannon, Ing-Chung Huang, Cheng-Chen Lin

The Mediating Effect of Pre/Post Assignment Acitivities on the Quality of Work Life of Expatriates:

Evidence for Managers in the P.R.C.

No. 94-019 John Hannon, Ing-Chung Huang, Cheng-Chen Lin

The Mediating Effects of Organization Commitment and Job Involvement on the Relationship Between Quality of Work Life and Customer Service Attitudes

No. 94-020 John A. Carlson, Marc Surchat

A Model for Filter-Rule Gains in Foreign Exchange Markets

No. 94-021 Ch.N. Noussair, Ch.R. Plott, R. Riezman

The Principles of Exchange Rate Determination in an International Finance Experiment

No. 94-022 Steven R. Goldberg, Joseph H. Godwin, Myung-Sun Kim, Charles A. Tritschler

On The Determinants of Corporate Hedging With Financial Derivatives

If you would like to request copies of specific papers, please contact the Center for International Business Education and Research, Purdue University, Krannert School of Management, West Lafayette, IN 47907.

(Phone: 317/494-4463 or FAX: 317/494-9658) 